\title{
EVALUASI IMPLEMENTASI STANDAR PENILAIAN PADA SEKOLAH ALAM BOGOR BERDASARKAN MODEL EVALUASI PROVUS
}

\author{
Fauzia Wida Fitria \\ Universitas Negeri Jakarta \\ Dinny Devi Triana \\ Fakultas Bahasa dan Seni \\ Universitas Negeri Jakarta
}

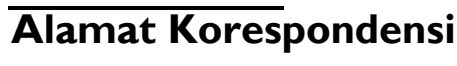 \\ e-mail: \\ fauzia.wida.fitria@gmail.com
}

\begin{abstract}
The objective of this research is to describe the discrepancy occurring between definition, instalation, process, and product by using a standard criteria. The research was conducted based on Provus evaluation model (Discrepancy Evaluation Model). Data were collected by using interview, quetioner, observation, and document analysis. Data was analyzed by using descriptive qualitative method and campared with the standard criteria. The subjects of the research consisted of Teachers and Head Master at Sekolah Alam Bogor. The results of the research showed that: (I) definition aspects were categorized as low, (2) installation aspects were categorized as moderate, (3) process aspects were categorized as moderate, and (4) product aspects were categorized as good.
\end{abstract}

\section{Keywords}

Provus evaluation model, assessment standar, implementation

\begin{abstract}
ABSTRAK
Tujuan penelitian ini untuk menjelaskan kesenjangan yang terjadi antara definisi, instalasi, proses, dan produk dengan menggunakan kriteria yang standar. Penelitian dilaksanakan dengan berdasarkan pada model evaluasi Provus (model evaluasi Kesenjangan). Data dikumpulkan melalui wawancara, kuesioner, observasi, dan analisis dokumen. Data dianalisis dengan menggunakan deskriptif kualitatif yang kemudian dibandingkan dengan kriteria standar. Subjek dalam penelitian ini terdiri atas guru dan kepala Sekolah Alam Bogor. Hasil menunjukkan bahwa: (I) Aspek definisi berada pada kategori rendah, (2) Aspek instalasi berada pada kategori sedang, (3) Aspek proses berada pada kategori sedang, dan (4) Aspek produk berada pada kategori baik.
\end{abstract}

\section{Kata Kunci}

Model evaluasi Provus, standar penilaian, implementasi

\section{Pendahuluan}

Penilaian hasil belajar oleh pendidik bertujuan untuk memantau proses, kemajuan peserta didik, dan perbaikan hasil pembelajaran. Penilaian hasil belajar oleh satuan pendidikan bertujuan untuk menilai pencapaian standar kompetensi lulusan untuk semua mata pelajaran sebagai bentuk transparansi, profesional, dan akuntabel lembaga. Sedangkan penilaian yang dilakukan oleh pemerintah bertujuan untuk menilai pencapaian kompetensi lulusan secara nasional pada mata pelajaran tertentu (oleh BSNP) serta digunakan sebagai salah satu pertimbangan untuk pemetaan mutu program, dasar seleksi masuk jenjang pendidikan berikutnya, penentuan kelulusan peserta didik, pembinaan, dan pemberian bantuan kepada sekolah dalam upaya peningkatan mutu pendidikan.

Dalam rangka mengendalikan mutu hasil pendidikan sesuai standar nasional yang dikembangkan oleh Badan Standar Nasional Pendidikan, maka penilaian hasil belajar peserta didik pada jenjang pendidikan dasar dan menengah dilaksanakan berdasarkan standar penilaian pendidikan yang berlaku secara nasional. Dari sekian banyak sekolah dasar dan menengah di Indonesia yang diatur dalam Badan Standar Nasional Pendidikan, salah satunya adalah Sekolah Menengah Sekolah Alam Bogor. Sekolah Alam pada dasarnya adalah bentuk pendidikan alternatif yang menggunakan alam semesta sebagai tempat belajar, bahan mengajar, dan juga sebagai objek pembelajaran. Dengan konsep pendidikan ini para peserta didik diharapkan dapat belajar dari alam 
lingkungan sekitar dan mengaitkan pelajaran serta menerapkan ilmu yang didapat dalam kehidupan nyata sehari-hari. Meski kurikulum tetap mengacu kepada Depdiknas, tetapi Sekolah Alam mengembangkan konsep sekolah berbasiskan alam. Metode belajar mengajarnya lebih banyak menggunakan action learning atau belajar aktif.

Walaupun Sekolah Alam Bogor memiliki konsep penilaian yang sudah dikembangkan sendiri, akan tetapi dalam pelaksanaannya harus tetap memenuhi kriteria yang sudah ditetapkan oleh Badan Standar Nasional Pendidikan karena peraturan ini ditujukan untuk jenjang pendidikan dasar dan menengah tanpa terkecuali agar sesuai dengan Standar Nasional. Untuk mengevaluasi proses penilaian yang telah diterapkan di Sekolah Alam Bogor menggunakan model evaluasi Provus (discrepancy evaluation model). Model evaluasi Provus dimaksudkan untuk mengetahui kelayakan suatu program di mana evaluator dapat membandingkan antara apa yang seharusnya dan diharapkan terjadi (standards) dengan apa yang sebenarnya terjadi (performance) sehingga dapat diketahui ada tidaknya kesenjangan (discrepancy) antara standar yang ditetapkan dengan kinerja.

Berdasarkan uraian tersebut, maka ada beberapa alasan yang melatarbelakangi perlunya melakukan evaluasi ini, antara lain: (I) belum adanya penelitian terhadap pelaksanaan penilaian yang bersifat evaluatif di Sekolah Alam Bogor meskipun sekolah tersebut telah terakreditasi, (2) pelaksanaan penilaian perlu dievaluasi secara kualitatif berdasarkan standar nasional yang telah dikeluarkan pemerintah, dan (3) hasil evaluasi dapat dijadikan informasi dan dasar pengambilan kebijakan pendidikan bagi semua elemen pendidikan yang terkait.

\section{Metode Penelitian}

Penelitian ini dikategorikan sebagai penelitian evaluasi dengan menggunakan pendekatan kualitatif. Secara umum penelitian ini bertujuan untuk memperoleh informasi tentang implementasi standar penilaian yang dilaksanakan oleh guru di Sekolah Alam Bogor. Sebagai penelitian evaluasi, penelitian ini juga bertujuan untuk mengetahui indikator-indikator yang mempengaruhi efektifitas pelaksanaan penilaian hasil belajar oleh guru dalam implementasi standar penilaian di Sekolah Alam Bogor. Secara konseptual, penelitian ini bertujuan untuk: I) meneliti dan mengevaluasi definisi, yaitu: pengetahuan tentang standar penilaian dan mengimplementasikannya, 2) meneliti dan mengevaluasi instalasi, yaitu: kesesuaian teknik penilaian yang digunakan untuk mencapai tujuan penilaian hasil belajar dalam implementasi standar penilaian, 3) meneliti dan mengevaluasi proses pelaksanaan penilaian hasil belajar dalam implementasi standar penilaian yang dilaksanakan oleh guru dan satuan pendidikan dengan standar penilaian pendidikan, dan 4) meneliti dan mengevaluasi produk yang dihasilkan oleh program ini berupa pelaporan hasil penilaian oleh pendidik dan satuan pendidikan.

\section{Hasil Penelitian dan Pembahasan}

Definisi, pada hasil evaluasi menggunakan angket dan wawancara terlihat perbedaan yang cukup signifikan antara fasilitator/guru dengan pihak sekolah. Pihak sekolah mengatakan sudah mempelajari dan mensosialisasikan standar penilaian kepada para guru akan tetapi pengetahuan para fasilitator tentang standar penilaian masih sangat kurang. Ada yang hanya sekedar mengetahui adanya standar penilaian tapi tidak mengetahui apa isinya, akan tetapi sebagian besar fasilitator tidak mengetahui sama sekali. Hal ini mungkin disebabkan kurangnya koordinasi dan pelatihan tentang standar penilaian yang rutin dilaksanakan, sehingga para fasilitator menjadi lupa dan guru yang baru belum mendapatkan pelatihan.

Instalasi, menurut hasil evaluasi didapatkan hasil sedang/moderat, hal ini disebabkan Sekolah Alam lebih fokus dengan teknik penilaian menggunakan worksheet, by project, dan by process, sehingga untuk teknik penilaian yang lain jarang digunakan.

Proses, dalam hasil evaluasi untuk kategori proses didapatkan hasil sedang/moderat, hal ini bukan berarti Sekolah Alam tidak menjalankan proses penilaian dengan baik, akan tetapi dalam prosesnya Sekolah Alam memiliki sistem sendiri yang telah disesuaikan dengan sistem di Sekolah Alam, yaitu: lebih ke penilaian sikap untuk raport 
deskriptif yang merupakan raport khas Sekolah Alam. Dalam pelaksanaannya mencakup dari proses sebagai berikut: I) perencanaan penilaian hasil belajar, dalam hasil evaluasi didapatkan hasil yang tinggi/baik disebabkan Sekolah Alam dalam pembuatan perencanaan telah mengikuti format yang ada di Diknas, 2) pelaksanaan penilaian hasil belajar, dalam hasil evaluasi untuk kategori proses didapatkan hasil sedang/moderat, hal ini bukan berarti Sekolah Alam tidak menjalankan proses penilaian dengan baik, akan tetapi dalam prosesnya Sekolah Alam memiliki sistem sendiri yang telah di sesuaikan dengan sistem di Sekolah Alam, yaitu: lebih ke penilaian sikap untuk raport deskriptif yang merupakan raport khas Sekolah Alam, 3) Analisis kualitas instrumen dan hasil penilaian hasil belajar, hasil evaluasi masuk kategori baik/tinggi yang artinya para guru di Sekolah Alam dalam penggunaan instrumen memenuhi kriteria keberhasilan. $\mathrm{Hal}$ ini disebabkan para guru/fasilitator dalam pembuatan instrumen menggunakan instrumen dari buku paket yang memang telah baku, dan 4) Penyampaian dan pemanfaatan hasil penilaian hasil belajar, dalam penyampaian dan pemanfaatan hasil penilaian hasil belajar Sekolah Alam tergantung dari fasilitator mata pelajaran masing-masing. Tidak ada aturan khusus yang mewajibkan untuk mengembalikan hasil penilaian dan pemberian feedback ke peserta didik. Akan tetapi untuk penilaian secara deskriptif, Sekolah Alam sudah memiliki aturan yang baku.

Hasil Penilaian, hasil capaian siswa pada semester sebelumnya, didapatkan 100\% siswa dapat mencapai KKM dalam semua mata pelajaran.

Pelaporan Penilaian dan Satuan Pendidikan, laporan penilaian Sekolah Alam terbagi menjadi dua, yaitu: raport nilai dan raport deskriptif khas Sekolah Alam dan untuk anak berkebutuhan khusus mendapatkan raport PPI yang dibuat oleh guru pendamping. Sekolah Alam rutin menyelenggarakan POMG, yaitu: pertemuan Orang Tua dan Guru serta memberikan laporan ke dinas pendidikan.

Berdasarkan hasil evaluasi yang telah dipaparkan, berikut ini akan dibahas hasil temuan penelitian yang berkenaan dengan kesenjangan yang terjadi dalam pelaksanaan implementasi standar penilaian di Sekolah Alam Bogor.

\section{a. Unit Pengoperasian Program (Program Operation)}

Tujuan evaluasi pengoperasian program adalah untuk memastikan bahwa program telah terpasang atau dilaksanakan sesuai dengan rancangan. Standar yang digunakan pada unit pengoperasian program adalah rancangan program yang diperoleh dari unit perancangan program.

Adapun komponen yang dibahas dalam unit pengoperasian program adalah komponen definisi, instalasi, dan proses. Berikut ini dijelaskan komponen-komponen dan aspek-aspek dalam pengoperasian implementasi standar penilaian di Sekolah Alam Bogor.

\section{I) Definisi}

Definisi merupakan pengetahuan tentang standar penilaian. Standar Penilaian Pendidikan merupakan kriteria mengenai mekanisme, prosedur, dan instrumen penilaian hasil belajar peserta didik yang diatur dalam Permendiknas Nomor 20 tahun 2007 tentang Standar Penilaian Indonesia, Permendikbud Nomor 66 Tahun 2013 tentang standar penilaian pendidikan dan Permendikbud Nomor 104 Tahun 2014 tentang penilaian hasil belajar oleh pendidik pada pendidikan dasar dan menengah. Untuk dapat mengimplementasikan standar penilaian, maka hal yang paling mendasar adalah pengetahuan tentang standar penilaian itu sendiri.

Pada hasil evaluasi menggunakan angket dan wawancara terlihat perbedaan yang cukup signifikan antara fasilitator/guru dengan pihak sekolah. Pihak sekolah mengatakan sudah mempelajari dan mensosialisasikan standar penilaian kepada para guru akan tetapi pengetahuan para fasilitator tentang standar penilaian masih sangat kurang. Ada yang hanya sekedar mengetahui adanya standar penilaian tapi tidak mengetahui apa isinya, akan tetapi sebagian besar fasilitator tidak mengetahui sama sekali.

$\mathrm{Hal}$ ini mungkin disebabkan kurangnya koordinasi dan pelatihan tentang standar penilaian yang rutin dilaksanakan, sehingga para fasilitator 
menjadi lupa dan guru yang baru belum mendapatkan pelatihan.

\section{2) Instalasi}

Instalasi dalam evaluasi implementasi standar penilaian di Sekolah Alam Bogor adalah teknik penilaian. Berdasarkan Permendiknas Nomor 20 Tahun 2007 tentang Standar Penilaian Indonesia, Permendikbud Nomor 66 Tahun 2013 tentang standar penilaian pendidikan dan Permendikbud Nomor 104 Tahun 2014 tentang penilaian hasil belajar oleh pendidik pada pendidikan dasar dan menengah, teknik penilaian adalah melakukan penilaian kompetensi sikap (observasi, penilaian diri, penilaian antar peserta didik, dan jurnal), melakukan penilaian kompetensi pengetahuan (tes tulis, tes lisan, dan penugasan), dan melakukan penilaian kompetensi keterampilan (penilaian kinerja, penilaian projek, dan portofolio). Menurut hasil evaluasi didapatkan hasil sedang/moderat, hal ini disebabkan Sekolah Alam lebih fokus dengan teknik penilaian menggunakan worksheet, by project dan by process, sehingga untuk teknik penilaian yang lain jarang digunakan.

\section{3) Proses}

Proses dalam evaluasi implementasi standar penilaian di Sekolah Alam Bogor meliputi mekanisme dan prosedur penilaian yang dilakukan oleh pendidik ataupun oleh satuan pendidikan. Berdasarkan Permendiknas Nomor 20 tahun 2007 tentang Standar Penilaian Indonesia, Permendikbud Nomor 66 Tahun 2013 tentang standar penilaian pendidikan dan Permendikbud Nomor 104 Tahun 2014 tentang penilaian hasil belajar oleh pendidik pada pendidikan dasar dan menengah, mekanisme dan prosedur penilaian meliputi perencanaan penilaian hasil belajar (sikap), pelaksanaan penilaian hasil belajar, analisis kualitas instrumen dan hasil penilaian hasil belajar (sikap, pengetahuan, dan keterampilan), penyampaian dan pemanfaatan hasil belajar (sikap, pengetahuan, dan keterampilan) yang dilakukan oleh pendidik dan satuan pendidikan.

Dalam hasil evaluasi untuk kategori proses didapatkan hasil sedang/moderat, hal ini bukan berarti Sekolah Alam tidak menjalankan proses penilaian dengan baik, akan tetapi dalam prosesnya Sekolah Alam memiliki sistem sendiri yang telah disesuaikan dengan sistem di Sekolah Alam, yaitu: lebih ke penilaian sikap untuk raport deskriptif yang merupakan raport khas sekolah alam mencakup dari proses sebagai berikut:

\section{a) Perencanaan Penilaian Hasil Belajar (Sikap, Pengetahuan, dan Keterampilan)}

Berdasarkan Permendiknas Nomor 20 Tahun 2007 tentang Standar Penilaian Indonesia, Permendikbud Nomor 66 Tahun 2013 tentang standar penilaian pendidikan dan Permendikbud Nomor 104 Tahun 2014 tentang penilaian hasil belajar oleh pendidik pada pendidikan dasar dan menengah, Perencanaan Penilaian Hasil Belajar (Sikap, Pengetahuan, dan Keterampilan), yaitu: terdapat aspek penilaian dalam RPP, membuat kisi-kisi instrumen, membuat instrumen penilaian, dan rubrik.

Dalam hasil evaluasi didapatkan hasil yang tinggi/baik disebabkan Sekolah Alam dalam pembuatan perencanaan telah mengikuti format yang ada di Diknas.

\section{b) Pelaksanaan Penilaian Hasil Belajar (Sikap, Pengetahuan, dan Keterampilan)}

Berdasarkan Permendiknas Nomor 20 Tahun 2007 tentang Standar Penilaian Indonesia, Permendikbud Nomor 66 Tahun 2013 tentang standar penilaian pendidikan dan Permendikbud Nomor 104 Tahun 2014 tentang penilaian hasil belajar oleh pendidik pada pendidikan dasar dan menengah, pelaksanaan penilaian hasil belajar adalah melaksanakan kuis, pemberian tugas, proyek, portofolio, tes, praktik, pengamatan, ulangan harian, UTS, UAS, UTK, dan UMTK. Dalam hasil evaluasi untuk kategori proses didapatkan hasil sedang/moderat, hal ini bukan berarti Sekolah Alam tidak menjalankan proses penilaian dengan baik, akan tetapi dalam prosesnya Sekolah Alam memiliki sistem sendiri yang telah disesuaikan dengan sistem di Sekolah Alam, yaitu: lebih ke penilaian sikap untuk raport deskriptif yang merupakan raport khas Sekolah Alam. 


\section{c) Analisis Kualitas Instrumen dan Hasil Penilaian Hasil Belajar (Sikap, Pengetahuan, dan Keterampilan)}

Berdasarkan Permendiknas Nomor 20 Tahun 2007 tentang Standar Penilaian Indonesia, Permendikbud Nomor 66 Tahun 2013 tentang standar penilaian pendidikan dan Permendikbud Nomor 104 Tahun 2014 tentang penilaian hasil belajar oleh pendidik pada pendidikan dasar dan menengah, analisis kualitas instrument, dan hasil penilaian hasil belajar adalah adanya kesesuaian secara substansi, konstruksi, dan bahasa, melakukan analisis kualitatif (tes dan nontes), melakukan analisis kuantitatif (tingkat kesukaran dan daya beda butir soal, realibilitas), pengolahan hasil penilaian. Hasil evaluasi masuk kategori baik/tinggi yang artinya para guru di Sekolah Alam dalam penggunaan instrumen memenuhi kriteria keberhasilan. $\mathrm{Hal}$ ini disebabkan para guru/fasilitator dalam pembuatan instrumen menggunakan instrumen dari buku paket yang memang telah baku.

\section{d) Penyampaian dan Pemanfaatan Hasil Penilaian Hasil Belajar (Sikap, Pengetahuan, dan Keterampilan)}

Berdasarkan Permendiknas Nomor 20 Tahun 2007 tentang Standar Penilaian Indonesia, Permendikbud Nomor 66 Tahun 2013 tentang Standar Penilaian Pendidikan dan Permendikbud Nomor 104 Tahun 2014 tentang penilaian hasil belajar oleh pendidik pada pendidikan dasar dan menengah adalah membuat laporan kualitatif dan kuantitatif, menyampaikan laporan ke pihak terkait, menggunakan hasil penilaian untuk perbaikan dan pengayaan, dan mengukur hasil pencapaian kompetensi anak didik. Dalam penyampaian dan pemanfaatan hasil penilaian hasil belajar Sekolah Alam tergantung dari fasilitator mata pelajaran masing-masing. Tidak ada aturan khusus yang mewajibkan untuk mengembalikan hasil penilaian dan pemberian feedback ke peserta didik. Akan tetapi untuk penilaian secara deskriptif, Sekolah Alam sudah memiliki aturan yang baku.

\section{b. Unit Hasil Sementara Program (Program Interim Products)}

Evaluasi hasil sementara program merupakan pengumpulan data pelaksanaan program untuk menentukan apakah telah berjalan dan berhasil sebagaimana yang diharapkan. Penilaian dilakukan terhadap pemenuhan tujuan jangka pendek dari program pendidikan yang diselenggarakan. Evaluasi hasil sementara program bertujuan untuk menyediakan sebuah perkiraan dampak elemenelemen proses terhadap elemen-elemen output dalam sebuah fungsi waktu. Dengan kata lain penilaian terhadap aspek hasil sementara program dilakukan pada periode atau jangka waktu tertentu.

Konteks evaluasi hasil sementara program bagi implementasi standar penilaian Sekolah Alam Bogor meliputi penilaian terhadap aspek hasil sementara program dalam kurun waktu tertentu. Oleh sebab itu untuk mengevaluasi hasil sementara digunakan hasil capaian siswa pada semester sebelumnya, di mana $100 \%$ siswa dapat mencapai KKM dalam semua mata pelajaran.

\section{c. Unit IV: Hasil Akhir Program (Program Terminal Product)}

Evaluasi hasil akhir program merupakan penentuan apakah tujuan akhir program tercapai. Evaluasi hasil akhir program bertujuan untuk membuat kajian tindak lanjut berdasarkan pencapaian tujuan paling akhir dari keseluruhan evaluasi program.

Berdasarkan Permendiknas Nomor 20 Tahun 2007 tentang Standar Penilaian Indonesia, Permendikbud Nomor 66 Tahun 2013 tentang standar penilaian pendidikan dan Permendikbud Nomor 104 Tahun 2014 tentang penilaian hasil belajar oleh pendidik pada pendidikan dasar dan menengah tentang pelaporan penilaian oleh pendidik adalah melaporkan nilai dan/atau deskripsi pencapaian kompetensi, untuk hasil penilaian kompetensi pengetahuan dan keterampilan, deskripsi sikap, untuk hasil penilaian kompetensi sikap spiritual dan sikap sosial, laporan disampaikan kepada pihak terkait (orang tua, wali kelas, dan guru BK) dan untuk pelaporan penilaian oleh satuan pendidikan adalah menerbitkan raport atau ijazah dan memberikan laporan kepada orang tua dan dinas pendidkan. 
Pelaporan hasil penilaian Sekolah Alam sudah mengikuti sesuai dengan yang ditetapkan dalam standar penilaian karena baik angket, observasi, wawancara, dan kriteria kualitatif semua menunjukkan hasil yang baik.

\section{Kesimpulan}

Berdasarkan hasil evaluasi yang sudah dijelaskan, maka implementasi standar penilaian di Sekolah Alam dapat disimpulkan. Kesimpulan berbentuk preposisi sesuai dengan fokus penelitian. Berdasarkan uraian pada pembahasan sebelumnya, maka dapat dirumuskan beberapa kesimpulan sebagai berikut:

\section{a. Definisi}

Pada hasil evaluasi menggunakan angket dan wawancara terlihat perbedaan yang cukup signifikan antara fasilitator/guru dengan pihak sekolah. Pihak sekolah mengatakan sudah mempelajari dan mensosialisasikan standar penilaian kepada para guru akan tetapi pengetahuan para fasilitator tentang standar penilaian masih sangat kurang. Ada yang hanya sekedar mengetahui adanya standar penilaian tapi tidak mengetahui apa isinya, akan tetapi sebagian besar fasilitator tidak mengetahui sama sekali. Hal ini mungkin disebabkan kurangnya koordinasi dan pelatihan tentang standar penilaian yang rutin dilaksanakan, sehingga para fasilitator menjadi lupa dan guru yang baru belum mendapatkan pelatihan.

\section{b. Instalasi}

Menurut hasil evaluasi didapatkan hasil sedang/moderat, hal ini disebabkan Sekolah Alam lebih fokus dengan teknik penilaian menggunakan worksheet, by project, dan by process, sehingga untuk teknik penilaian yang lain jarang digunakan.

\section{c. Proses}

Dalam hasil evaluasi untuk kategori proses didapatkan hasil sedang/moderat, hal ini bukan berarti Sekolah Alam tidak menjalankan proses penilaian dengan baik, akan tetapi dalam prosesnya Sekolah Alam memiliki Sistem sendiri yang telah disesuaikan dengan sistem di Sekolah Alam, yaitu: lebih ke penilaian sikap untuk raport deskriptif yang merupakan raport khas sekolah alam. Dalam pelaksanaannya mencakup dari proses sebagai berikut:

\section{I) Perencanaan Penilaian Hasil Belajar (Sikap, Pengetahuan, dan Keterampilan)}

Dalam hasil evaluasi didapatkan hasil yang tinggi/baik disebabkan Sekolah Alam dalam pembuatan perencanaan telah mengikuti format yang ada di Diknas.

\section{2) Pelaksanaan Penilaian Hasil Belajar (Sikap, Pengetahuan, dan Keterampilan)}

Dalam hasil evaluasi untuk kategori proses didapatkan hasil sedang/moderat, hal ini bukan berarti Sekolah Alam tidak menjalankan proses penilaian dengan baik, akan tetapi dalam prosesnya Sekolah Alam memiliki sistem sendiri yang telah disesuaikan dengan sistem di Sekolah Alam, yaitu: lebih kepenilaian sikap untuk raport deskriptif yang merupakan raport khas sekolah alam.

\section{3) Analisis Kualitas Instrumen dan Hasil Penilaian Hasil Belajar (Sikap, Pengetahuan, dan Keterampilan)}

Hasil evaluasi masuk kategori baik/tinggi yang artinya para guru di Sekolah Alam dalam penggunaan instrumen memenuhi kriteria keberhasilan. Hal ini disebabkan para guru/fasilitator dalam pembuatan instrumen menggunakan instrumen dari buku paket yang memang telah baku.

\section{4) Penyampaian dan Pemanfaatan Hasil Penilaian Hasil Belajar (Sikap, Pengetahuan, dan Keterampilan)}

Dalam penyampaian dan pemanfaatan hasil penilaian hasil belajar Sekolah Alam tergantung dari fasilitator mata pelajaran masing-masing. Tidak ada aturan khusus yang mewajibkan untuk mengembalikan hasil penilaian dan pemberian feedback ke peserta didk. Akan tetapi untuk penilaian secara deskriptif, Sekolah Alam sudah memiliki aturan yang baku. 


\section{d. Hasil Penilaian}

Hasil capaian siswa pada semester sebelumnya, didapatkan 100\% siswa dapat mencapai KKM dalam semua mata pelajaran.

\section{e. Pelaporan Penilaian Pendidik dan Satuan Pendidikan}

Laporan penilaian Sekolah Alam terbagi menjadi dua, yaitu: raport nilai dan raport deskriptif khas Sekolah Alam dan untuk anak berkebutuhan khusus mendapatkan raport PPI yang dibuat oleh guru pendamping. Sekolah Alam rutin menyelenggarakan POMG, yaitu: pertemuan Orang Tua dan Guru serta memberikan laporan ke dinas pendidikan.

\section{Daftar Pustaka}

Aiken, Lewis R. (1996). Rating Scales and Checklist: Evaluation Behavior Personality, and Attitude. New York: John Wiley \& Sons Inc.

Arikunto, Suharsimi dan Jabar, Cepi Safrudin Abdul. (2009). Evaluasi Program Pendidikan: Pedoman Teoritis Praktis Bagi Mahasiswa dan Praktisi Pendidikan. Jakarta: Bumi Aksara.

Provus, Malcolm M. (1969). The Discrepancy Evaluation Model: An Approach to Local Improvement and Development. Pennsylvania: U.S. Departement or Health, Education \& Welfare Office of Education.

Departemen Pendidikan dan Kebudayaan. (2008). Kamus Besar Bahasa Indonesia. Jakarta: Balai Pustaka.

Departemen Pendidikan Nasional. (2008). Modul pelatihan Praktik yang Baik. Jakarta.
Depdiknas. (2008). Perangkat Penilaian Kurikulum Tingkat Satuan Pendidikan KTSP SMA. Jakarta: Direktorat Jendral Manajemen Pendidikan Dasar dan Menegah Direktorat Pembinaan Sekolah Menegah Atas.

Lampiran Peraturan Menteri Pendidikan dan Kebudayaan Republik Indonesia Nomor 104 tahun 2014 tentang Penilaian Hasil Belajar oleh Pendidik pada Pendidikan Dasar dan Menengah. Jakarta: Kementerian Pendidikan dan Kebudayaan Republik Indonesia, 2014.

Lampiran Peraturan Menteri Pendidikan Kebudayaan Republik Indonesia Nomor 66 Tahun 2013 tentang Standar Penilaian Pendidikan. Jakarta: Kementerian Pendidikan dan Kebudayaan Republik Indonesia, 2013.

Lampiran Standar Penilaian Pendidikan. Jakarta: Kementerian Pendidikan dan Kebudayaan Republik Indonesia, 2013.

Peraturan Menteri Pendidikan dan Kebudayaan Republik Indonesia Nomor 66 tahun 2013 tentang Standar Penilaian Pendidikan, Pasal I, ayat I.

Peraturan Menteri Pendidikan Kebudayaan Republik Indonesia Nomor 104 Tahun 2014 tentang Penilaian Hasil Belajar oleh Pendidik pada Pendidikan Dasar dan Menengah, Pasal 7, ayat I-3.

Peraturan Pemerintah Republik Indonesia Nomor 32 Tahun 2013 tentang Perubahan Atas Peraturan Pemerintah Nomor 19 Tahun 2005 tentang Standar Nasional Pendidikan 